\title{
AGRONOMIC CHARACTERISTICS AND GRAIN YIELD OF SORGHUM AND MAIZE HYBRIDS GROWN WITH DIFFERENT SOWING TIMES ${ }^{1}$
}

\author{
PAULO VINICIUS DEMENECK VIEIRA ${ }^{2}$, PAULO SÉRGIO LOURENÇO DE FREITAS ${ }^{2}$, ANDRÉ LUIZ BISCAIA \\ RIBEIRO DA SILVA ${ }^{3}$, ANA CLAUDIA SOSSAI SOUZA ${ }^{2}$, JULIANA MARQUES VORONIAK ${ }^{2}$
}

\begin{abstract}
Sorghum is a commonly grown plant in the Central-West region of Brazil as a second crop; however, it is grown almost exclusively as a second crop after maize in the state of Paraná (South region). The growth of sorghum crops is an option for areas or times in which the growth of maize crops can be risky. Thus, the objective of this work was to evaluate the agronomic characteristics of eight sorghum hybrids (ADV-123, ADV-114, 1G100, 50A10, 1G244, 50A40, 50A50, and 1G282) grown in three sowing times in two agricultural years: 2014 (February 20, March 02, and March 03) and 2015 (February 09, February 19, and March 01), and four maize hybrids in 2014 (DKB-330-Pro, P-3431-HX, Formula-TL, and AG-9010-Pro) and five maize hybrids in 2015 (DKB-330-Pro, P-3431-HX, Formula-TL, DKB-275-Pro, and DKB-290-Pro), in the same sowing times used for sorghum. A randomized complete block experimental design with a split-plot factorial arrangement was used, with the sowing times in the plots and the hybrids in the sub-plots. The variables evaluated were: number of days from sowing to flowering, leaf area index, 1,000-grain weight, grain yield, number of spikelets per panicle, for the sorghum crop; and number of rows per ear and number of grains per row, for the maize crop. The comparison between the two crops showed that the sorghum maintained higher production stability in the different sowing times.
\end{abstract}

Keywords: Paraná. Winter crop. Sorghum bicolor. Zea mays.

\section{CARACTERÍSTICAS AGRONÔMICAS E PRODUTIVIDADE DE HÍBRIDOS DE SORGO E MILHO CULTIVADOS EM DIFERENTES DATAS DE SEMEADURA}

RESUMO - O sorgo é uma cultura muito utilizada no Centro-Oeste brasileiro em cultivo de segunda safra, contudo, no Paraná a mesma é feita quase exclusivamente com a cultura do milho. O cultivo de sorgo pode ser uma opção de semeadura em áreas ou épocas cuja a cultura do milho possa ser considerada de risco. Assim, objetivou-se com trabalho avaliar as características agronômicas de oito híbridos de sorgo (ADV 123, ADV $114,1 \mathrm{G} 100,50 \mathrm{~A} 10,1 \mathrm{G} 244,50 \mathrm{~A} 40,50 \mathrm{~A} 50$ e 1G282), em três datas de semeadura nos anos agrícolas de 2014 $(20 / 02,02 / 03$ e 12/03) e $2015(09 / 02,19 / 02$ e 01/03) e quatro híbridos de milho em 2014 (DKB 330 Pro, P 3431 HX, Formula TL e AG 9010 Pro) e cinco híbridos no ano de 2015 (DKB 330 Pro, P 3431 HX, Formula TL, DKB 275 Pro e DKB 290 Pro), nas mesmas datas de semeadura utilizada para o sorgo. O delineamento experimental foi em blocos completos casualizados em esquema fatorial em parcelas subdivididas, sendo nas parcelas alocadas as datas de semeadura e nas sub parcelas os híbridos. Foi avaliado o número de dias da semeadura até o florescimento (DAP), índice de área foliar (IAF), massa de mil grãos (MMG), produtividade $\left(\mathrm{kg} \mathrm{ha}^{-1}\right)$ número de espiguetas por panícula no sorgo (EPP), e no milho o número de fileiras por espiga (NFE) e número de grãos por fileira (NGF). Ao comparar as culturas, o sorgo conseguiu manter maior estabilidade produtiva em diferentes datas de semeadura.

Palavras-chave: Paraná. Safrinha. Sorghum bicolor. Zea mays.

\footnotetext{
*Corresponding author

${ }^{1}$ Received for publication in $08 / 13 / 2020$; accepted in $05 / 31 / 2021$.

Paper extracted from the doctoral thesis of the first author.

${ }^{2}$ Agricultural Sciences Department, Universidade Estadual de Maringá, Maringá, PR, Brazil; pvinicius1988@gmail.com - ORCID: 00000001-9542-2713, pslfreitas@uem.br - ORCID: 0000-0001-6663-2797, ana_sossai87@hotmail.com - ORCID: 0000-0001-8628-4734, juliana.voroniak@hotmail.com - ORCID: 0000-0001-8374-6622.

${ }_{3}^{3}$ Department of Horticulture, Universidade de Auburn, AL, United States of America; dehbiscaia@gmail.com - ORCID: 0000-0003-47544227.
} 


\section{INTRODUCTION}

The central-west region of the state of Paraná, Brazil, has stood out in the Brazilian agricultural scenario; it is a pioneer region for the practice of two harvests in the same agricultural year, namely, first crop and second crop. The second crop is characterized by higher risks of occurrence of frosts and dry spells.

A late sowing of maize (Zea mays L.) affects negatively yield components and grain yield, mainly due to the unfavorable climate conditions, mainly temperature, solar radiation, and rainfall (TSIMBA et al., 2014; BONELLI et al., 2016; ZHOU et al., 2016; LU; XUE; GUO, 2017). The sowing time for the second crop is between January and March, when the temperature, solar radiation, and rainfall volume and frequency are usually insufficient and oscillate, decreasing the probability to meet the adequate water demand of most crops (GOES et al., 2011).

Zucareli et al. (2013) evaluated 12 maize hybrids as second crop in northern state of Paraná and found mean grain yield of $6.648 \mathrm{~kg} \mathrm{ha}^{-1}$. Shioga and Gerage (2010) evaluated sowing times for maize in different locations in Paraná and reported that the weather conditions affected the flowering (days) and grain yield $\left(\mathrm{kg} \mathrm{ha}^{-1}\right)$ responses; the low temperature was the main factor that affected the flowering due to the low degree-day accumulation. In addition, they found that the lowest temperatures, with occurrence of frosts, and dry spell periods had more effect on grain yield as the sowing time is delayed.

Therefore, the search for alternative crops to substitute maize as second crop for this region, is needed. Tardin et al. (2013) pointed out several reasons that make grain sorghum crop (Sorghum bicolor L.) a better option than other cereals, mainly maize, to grow under stress conditions. Sorghum is a good option for grain production in the second crop season, which presents the lowest rainfall frequency volumes because it is a xerophyte (AMADUCCI et al., 2016) that has high sowing time amplitude and crop implementation flexibility.

Albuquerque et al. (2011) evaluated grain sorghum cultivars under semiarid conditions and found grain yields between 5.500 and $7.000 \mathrm{~kg} \mathrm{ha}^{-1}$ in a rainy year and lower than $3.000 \mathrm{~kg} \mathrm{ha}^{-1}$ in a dry year. Silva et al. (2013) and Almeida Filho et al. (2014) evaluated pre-commercial hybrids and found yields of $5.150 \mathrm{~kg} \mathrm{ha}^{-1}$ and $4.400 \mathrm{~kg} \mathrm{ha}^{-1}$, respectively; these results were correlated with the sowing times and high availability and distribution of water in the study regions.

Thus, performance evaluations of sorghum and maize cultivars are needed for grain producing regions to make technical information regarding the use of these crops in production systems available to farmers.

In this context, the objective of this work was to evaluate agronomic and production characteristics of different sorghum and maize hybrids in three sowing times in the second crop season in the central -west region of Paraná.

\section{MATERIAL AND METHODS}

The experiments were conducted in the agricultural years of 2014 and 2015, using maize and sorghum crops under rainfed conditions in the municipality of Juranda, state of Paraná, Brazil (24 $23^{\prime} 10^{\prime \prime} \mathrm{S}, 52^{\circ} 49^{\prime} 30^{\prime \prime} \mathrm{W}$, and altitude of $570 \mathrm{~m}$ ). The soil of the area was classified as a Typic Hapludox (Latossolo Vermelho distroférrico; EMBRAPA, 2013). The predominant climate of the region is Cfa, sub-tropical wet, according to the Köppen classification, with mean annual temperature of $22.2{ }^{\circ} \mathrm{C}$ and annual rainfall depth of approximately $2.100 \mathrm{~mm}$.

Data of maximum and minimum air temperatures, relative air humidity, solar radiation, rainfall, and wind speed were obtained from a meteorological station (Davis Vantage Pro 2) installed in the study area.

A randomized complete block experimental design was used, in a split-plot factorial arrangement, with sowing times (according to the agroclimatic zoning for the region of Paraná) in the plots, and hybrids in the subplots. The sorghum crop tests were conducted with three blocks, using eight hybrids, four of very-early maturation cycle (ADV123, ADV-114, $1 \mathrm{G} 100$ and 50A10), three of early maturation cycle (1G244, 50A40 and 50A50) and one of normal cycle (1G282) grown in three sowing times (February 20, March 02, and March 03) and (February 09, February 19, and March 01) in the agricultural years of 2014 and 2015, respectively.

The maize crop tests were conducted with four blocks, using four very-early maturation hybrids (DKB-330-Pro, P-3431-HX, Formula-TL, and AG9010-Pro) grown in three sowing times (February 20, March 02, and March 03) in 2014. The evaluations of the two latest sowing times were not carried out because all plants in the plots had been lodged by wind. In 2015, five maize hybrids were used, four of very-early maturation cycle (DKB-330-Pro, P-3431HX, Formula-TL, and DKB-275-Pro) and one of early maturation cycle (DKB-290-Pro), in three sowing times (February 09, February 19, and March 01 ), using four blocks, although the last harvest had been not possible due to the lodging of the plants.

Soil fertilizers were applied at sowing using $210 \mathrm{~kg} \mathrm{ha}^{-1}$ of the $\mathrm{N}-\mathrm{P}_{2} \mathrm{O}_{5}-\mathrm{K}_{2} \mathrm{O}$ formulation $08-20-20$, and $40 \mathrm{~kg} \mathrm{ha}^{-1}$ of nitrogen was used as topdressing at the V4 stage for both crops (TEDESCO et al., 2004).

The maize and sorghum experimental plots consisted of six 6-meter rows spaced $0.70 \mathrm{~m}$ apart, and the evaluation area consisted of the four central meters of the two central rows. The maize was sown using approximately 4.3 seeds per meter, resulting in 
a final population of approximately 58.000 plants per hectare. The sorghum was sown using approximately 22 seeds per meter to a final population of approximately 280.000 plants per hectare.

The agronomic performance characterization of the sorghum and maize hybrids were carried out using information collected over the crop cycle. The variables evaluated were: a) number of days from sowing to flowering (DSF), considering the time that $50 \%$ of the plants in the plots were releasing pollen as flowering; b) number of spikelets per panicle (NSPP) in the sorghum crop; c) number of rows per ear (NRE) in the maize crop; d) number of grains per row (NGF) in the maize crops; e) leaf area index (LAI), measured by multiplying the leaf area (maximum leaf length multiplied by its width and then by the correction factor 0.75; (FRANCIS RUTGER; PALMER, 1969) by the area occupied per plant (ratio between number of plants and the area used); f) grain yield $\left(\mathrm{kg} \mathrm{ha}^{-1}\right)$, yield of grains obtained by harvesting and threshing of plants in the evaluation area of each plot, the weight of grains was corrected to a moisture of $13 \%$ and then transformed into $\mathrm{kg} \mathrm{ha}^{-1}$; and g) 1,000-grain weight (1000GW; g).

The data were subjected to tests of normality (Kolmogorov-Smirnov) and homogeneity (Cochran) of errors and then subjected to analysis of variance at $5 \%$ probability by the Fisher test. The means were compared using the Scott-Knott grouping test at $10 \%$ probability level. The SAS 9.1.3 and SISVAR 5.3 (Build 77) programs was used for the statistical analyses.

\section{RESULTS AND DISCUSSION}

\section{Sorghum crop}

Regarding the agronomic and yield characterization of the hybrids, the number of spikelets per panicle (NSPP) and 1,000-grain weight (1000GW) of sorghum crops in 2015 did not met the basic assumptions for the analysis of variance and the subsequent Scott-Knott grouping test, even after the transformation of the data.

The sowing times in 2014 presented, in general, high variation between hybrids; the veryearly maturation hybrids presented $7 \%$ to $11 \%$ faster maturation then the others, whereas in 2015 , these differences were 2.7 to $5.8 \%$.

The hybrids ADV-123, ADV-114, 1G100, and $50 \mathrm{~A} 10$ required lower number of days to reach $50 \%$ flowering (DSF) in 2014, mainly in the first sowing time, in which hybrids of different maturation cycles (1G244, 1G282, 50A40, and 50A50) presented statistically higher DSF by the Scott-Knott test and within the group of very-early maturation hybrids (Table 1).

Table 1. Number of days from sowing to flowering of sorghum crops grown in three sowing times in 2014 and 2015.

\begin{tabular}{ccccccc}
\hline \multirow{2}{*}{ Hybrid } & \multicolumn{5}{c}{2014} & \multicolumn{2}{c}{2015} \\
\cline { 2 - 6 } & February 20 & March 02 & March 03 & February 09 & February 19 & March 01 \\
\hline ADV-123 & $62 \mathrm{bB}$ & $66 \mathrm{bA}$ & $68 \mathrm{bA}$ & $59 \mathrm{bB}$ & $62 \mathrm{cA}$ & $59 \mathrm{~dB}$ \\
ADV-114 & $57 \mathrm{cC}$ & $61 \mathrm{cB}$ & $65 \mathrm{cA}$ & $60 \mathrm{bA}$ & $61 \mathrm{cA}$ & $56 \mathrm{eB}$ \\
$1 \mathrm{G} 100$ & $57 \mathrm{cB}$ & $60 \mathrm{cB}$ & $64 \mathrm{cA}$ & $60 \mathrm{bB}$ & $63 \mathrm{cA}$ & $57 \mathrm{eC}$ \\
$1 \mathrm{G} 244$ & $67 \mathrm{aB}$ & $67 \mathrm{bB}$ & $75 \mathrm{aA}$ & $64 \mathrm{aA}$ & $65 \mathrm{bA}$ & $63 \mathrm{cA}$ \\
$1 \mathrm{G} 282$ & $66 \mathrm{aB}$ & $68 \mathrm{bA}$ & $70 \mathrm{aA}$ & $64 \mathrm{aA}$ & $65 \mathrm{bA}$ & $65 \mathrm{bA}$ \\
$50 \mathrm{~A} 10$ & $60 \mathrm{bC}$ & $65 \mathrm{bB}$ & $72 \mathrm{aA}$ & $62 \mathrm{aB}$ & $65 \mathrm{bA}$ & $63 \mathrm{cA}$ \\
$50 \mathrm{~A} 40$ & $69 \mathrm{aB}$ & $73 \mathrm{aA}$ & $74 \mathrm{aA}$ & $65 \mathrm{aB}$ & $68 \mathrm{aA}$ & $67 \mathrm{aA}$ \\
$50 \mathrm{~A} 50$ & $66 \mathrm{aB}$ & $68 \mathrm{bB}$ & $71 \mathrm{aA}$ & $63 \mathrm{aB}$ & $67 \mathrm{aA}$ & $64 \mathrm{cB}$ \\
\hline CV $(\%)$ & & 3.25 & & 2.07 & \\
\hline
\end{tabular}

Means followed by the same lowercase letter in the columns, or uppercase in the rows, are not different from each other by the Scott-Knott test at $10 \%$ probability level.

The hybrids ADV-114 and $1 \mathrm{G} 100$ presented lower and statically different DSF than the ADV-123 and $50 \mathrm{~A} 10$ by the Scott-Knott test, although they belong to the same maturation group. The hybrids ADV-114 and 1 G100 presented earlier maturation in the sowing on March 02. The hybrid 50A40 was the most late, and the other treatments were within an intermediate level, despite being from different maturation groups. Only the hybrid 50A10 (veryearly maturation cycle), had a late flowering in the third sowing time and was grouped together with longer cycle hybrids.

The sowing on February 09, 2015, presented similar results to the that found for the sowing on 
March 12, 2014, except for the hybrid 50A10, the other very-early maturation hybrids were grouped together. These results were repeated for the sowing on February 19 and March 01, however, the hybrid 50A10 was within the intermediate group (Table 1).

The mean DSF of all hybrids, from the first to the last sowing time, was $9.8 \%$ and $3.5 \%$, for 2014 and 2015, respectively; thus, the earlier the sowing the lowest the cycle variation between hybrids.

The DSF in 2014 within each sowing time showed that all hybrids presented longer cycle when using the late sowing. The hybrids ADV-114 and 50A10 presented higher sensitivity, both of veryearly maturation cycle, which differed in the three sowing times. The hybrids ADV-123, 1G282, and 50A40 did not vary significantly $(p<0.10)$ between the second and third sowing time, whereas the other showed difference only between the last and the two first sowing times.

Comparing the hybrids within the sowing times, the sowing on February 19, 2015 presented higher DSF than the last sowing time for three veryearly maturation hybrids (ADV-123, ADV-114 and $1 \mathrm{G100}$ ) and for the early maturation cycle hybrid 50A50; a normal result would be the last sowing time presenting a higher DSF when compared to the two first sowing times.

This result is due to the high rainfall depths and low temperatures at the beginning of the crop cycle as a function of the different sowing times; contrasting with the results found in 2014, which presented rainfall variation and distribution at the beginning of the development of the three most homogeneous sowing times (Figure $1 \mathrm{~A}$ and $1 \mathrm{~B}$ ).

A

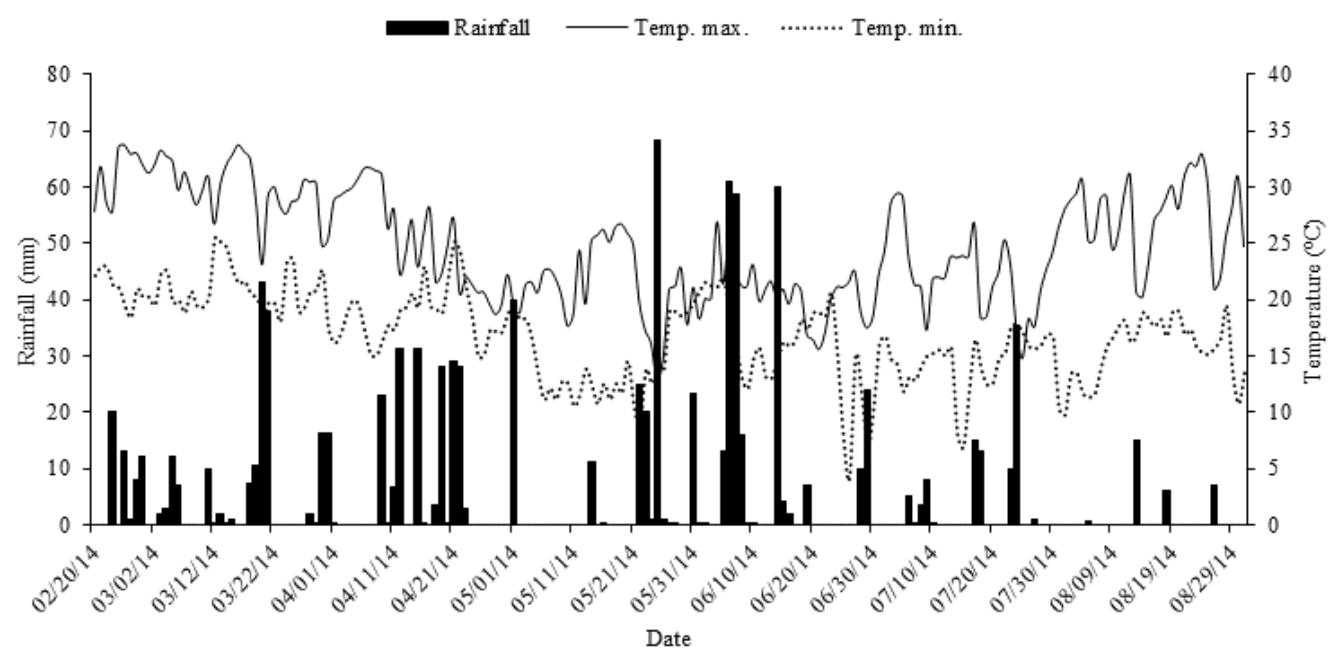

B

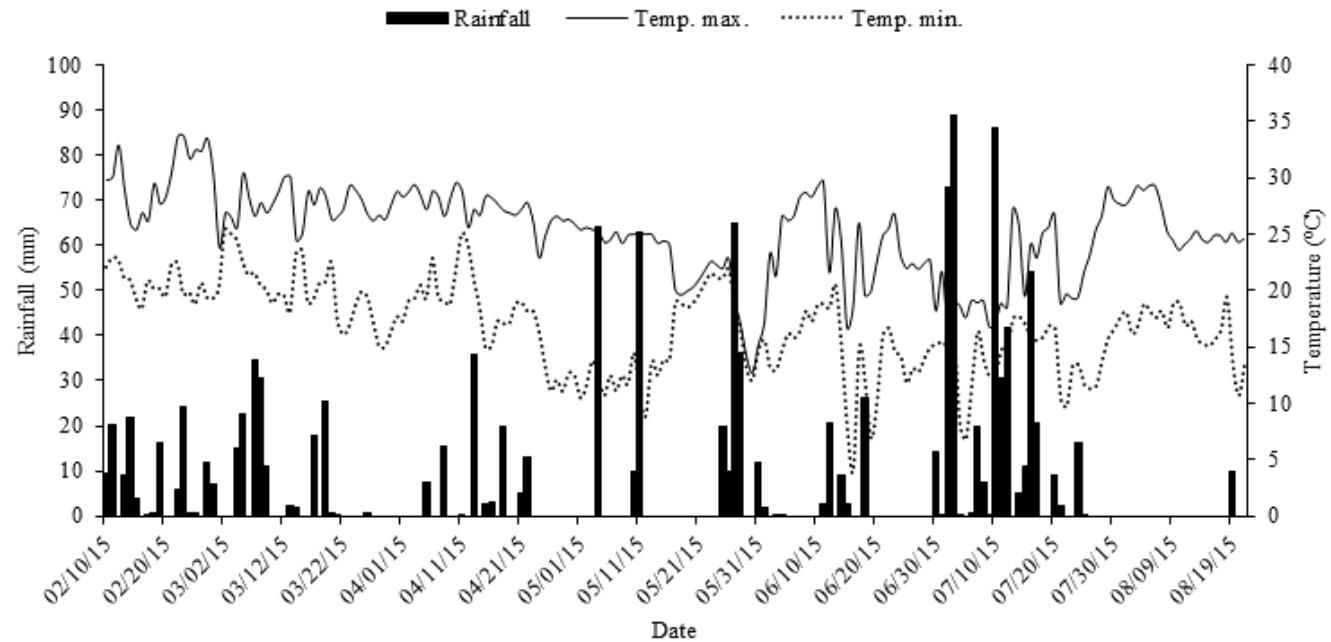

Figure 1. Maximum and minimum temperatures $\left({ }^{\circ} \mathrm{C}\right)$ and daily rainfall $(\mathrm{mm})$ throughout the experiment in $2014(\mathrm{~A})$ and 2015 (B). Source: Weather station of the experimental area. 
Thus, as well as second crop maize, sorghum may be sown in January, focused on minimize losses related to water deficit, mainly in critical periods for the crop and under low temperatures, which affect grain yield and contribute to increases in the time required for the crop to reach the flowering period (LANDAU; SANS; SANTANA, 2010).

The hybrids ADV-123 and 50A40 presented statistically lower number of spikelets per panicle
(NSPP) when compared to the other hybrids in all sowing times (Table 2). The hybrid $1 \mathrm{G} 282$ had statistically higher NSPP (60 NSPP) in the second sowing time, whereas the other hybrids had 45 to 56 EEP. The hybrid ADV-114 presented the highest NSPP, considering all treatments in the third sowing time, and the highest NSPP for the sowing time February 20, together with other three hybrids, however, numerically higher than the others.

Table 2. Mean number of spikelets per panicle of sorghum plants grown in three sowing times in 2014 .

\begin{tabular}{cccc}
\hline \multirow{2}{*}{ Hybrid } & \multicolumn{3}{c}{ Sowing time } \\
\cline { 2 - 4 } & February 20 & March 02 & March 03 \\
\hline ADV-123 & $48 \mathrm{cA}$ & $47 \mathrm{cA}$ & $44 \mathrm{cA}$ \\
ADV-114 & $63 \mathrm{aA}$ & $54 \mathrm{bB}$ & $55 \mathrm{aB}$ \\
$1 \mathrm{G} 100$ & $55 \mathrm{bA}$ & $56 \mathrm{bA}$ & $50 \mathrm{bB}$ \\
$1 \mathrm{G} 244$ & $59 \mathrm{aA}$ & $55 \mathrm{bA}$ & $51 \mathrm{bB}$ \\
$1 \mathrm{G} 282$ & $59 \mathrm{aA}$ & $60 \mathrm{aA}$ & $51 \mathrm{bB}$ \\
$50 \mathrm{~A} 10$ & $60 \mathrm{aA}$ & $55 \mathrm{bB}$ & $50 \mathrm{bC}$ \\
$50 \mathrm{~A} 40$ & $46 \mathrm{cA}$ & $45 \mathrm{cA}$ & $45 \mathrm{cA}$ \\
$50 \mathrm{~A} 50$ & $54 \mathrm{bA}$ & $54 \mathrm{bA}$ & $51 \mathrm{bA}$ \\
\hline CV (\%) 4.65 & & & \\
\hline
\end{tabular}

Means followed by the same lowercase letter in the columns, or uppercase in the rows, are not different from each other by the Scott-Knott test at $10 \%$ probability level.

The last sowing time presented the lowest NSPP, except for the hybrids ADV-123 and 50A40, which had the lowest means in all sowing times, and the hybrid 50A50 which had no different NSPP between sowing times. It was not found a correlation between NSPP and the different maturation groups in the evaluation between sorghum hybrids.

The leaf area index (LAI) showed a different dynamic between the years regarding the sowing time (Table 3). In 2014, the LAI decreased, on average, $20 \%$ from the first (February 20) to the second (March 02) sowing time, and 16\% from the third (March 03) to the second (March 02). In 2015, when the crop was sowed earlier, the LAI increased, on average, $2 \%$ from the second (February 19) to the first (February 09) sowing time and decrease 13\% from the third (March 01) to the second (February 19) sowing time, with similar results to those found in 2014 between the sowing times March 02 and February 20.

The latest sowing times, such as March 12, 2014, showed higher segregation of means of hybrids, regardless of the maturation cycle, with decreases in LAI as the sowing was delayed, except for the hybrids $1 \mathrm{G} 100,1 \mathrm{G} 282$, and 50A10. The hybrids that composed the group of lowest means for the sowing time February 20, 2014 were those of very-early maturation cycle (ADV-123, ADV-114, $1 \mathrm{G} 100$ and 50A10), similar results to that found in the sowing on February 09 and 19, 2015. The difference between the hybrids in 2015 was detected in the two first sowing time, since all treatments in the last sowing time presented no significant variation of means.

The hybrids 1G282, 50A40, and 50A50 stood out with the highest LAI, regardless of the sowing time. Thus, the higher LAI of these hybrids are probably related to their cycle (Table 1), since plants of longer vegetative cycle present higher leaf area development.

The results of 1,000-grain weight $(1000 \mathrm{GW})$ vary between sowing times only in two treatments; the hybrids 1G282 and 50A40 presented higher $1000 \mathrm{GW}$ in the third sowing time (Table 4). In the second sowing time, very-early maturation hybrids (ADV-123, ADV-114, 1G100, and 50A10) stood out with a higher mean $1000 \mathrm{GW}$ than the other hybrids; this result was not found for the sowing on February 20 and March 12, 2014, in which the difference between hybrids were not related to their maturation groups. The mean $1000 \mathrm{GW}$, considering all hybrids and sowing times, was approximately 28 grams. 
P. V. D. VIEIRA et al.

Table 3. Mean leaf area index of sorghum crops grown in three sowing times in 2014 and 2015.

\begin{tabular}{ccccccc}
\hline \multirow{2}{*}{ Hybrid } & \multicolumn{5}{c}{2014} & \multicolumn{5}{c}{2015} \\
\cline { 2 - 7 } & February 20 & March 02 & March 03 & February 09 & February 19 & March 01 \\
\hline ADV-123 & $3.35 \mathrm{bA}$ & $2.83 \mathrm{aA}$ & $1.72 \mathrm{cB}$ & $3.35 \mathrm{bA}$ & $2.91 \mathrm{bA}$ & $2.82 \mathrm{aA}$ \\
ADV-114 & $3.64 \mathrm{bA}$ & $2.48 \mathrm{aB}$ & $1.82 \mathrm{cB}$ & $2.09 \mathrm{cA}$ & $3.37 \mathrm{bA}$ & $2.73 \mathrm{aA}$ \\
$1 \mathrm{G} 100$ & $3.25 \mathrm{bA}$ & $3.06 \mathrm{aA}$ & $2.04 \mathrm{cA}$ & $5.03 \mathrm{aA}$ & $3.28 \mathrm{bB}$ & $2.88 \mathrm{aB}$ \\
$1 \mathrm{G} 244$ & $3.94 \mathrm{aA}$ & $3.16 \mathrm{aA}$ & $2.19 \mathrm{cB}$ & $3.24 \mathrm{bA}$ & $3.42 \mathrm{bA}$ & $3.10 \mathrm{aA}$ \\
$1 \mathrm{G} 282$ & $3.96 \mathrm{aA}$ & $3.48 \mathrm{aA}$ & $2.98 \mathrm{bA}$ & $4.60 \mathrm{aA}$ & $4.76 \mathrm{aA}$ & $3.53 \mathrm{aB}$ \\
$50 \mathrm{~A} 10$ & $3.52 \mathrm{bA}$ & $3.16 \mathrm{aA}$ & $2.67 \mathrm{bA}$ & $3.37 \mathrm{bA}$ & $3.94 \mathrm{aA}$ & $3.30 \mathrm{aA}$ \\
$50 \mathrm{~A} 40$ & $4.68 \mathrm{aA}$ & $3.46 \mathrm{aB}$ & $3.79 \mathrm{aB}$ & $4.08 \mathrm{aA}$ & $4.52 \mathrm{aA}$ & $3.42 \mathrm{aA}$ \\
$50 \mathrm{~A} 50$ & $4.17 \mathrm{aA}$ & $2.49 \mathrm{aB}$ & $2.90 \mathrm{bB}$ & $3.79 \mathrm{aA}$ & $3.90 \mathrm{aA}$ & $4.09 \mathrm{aA}$ \\
\hline CV $(\%)$ & \multicolumn{7}{c}{18.81} & & 18.46 & \\
\hline
\end{tabular}

Means followed by the same lowercase letter in the columns, or uppercase in the rows, are not different from each other by the Scott-Knott test at 10\% probability level.

Table 4. Mean 1,000-grain weight (g) of sorghum crops grown in three sowing times in 2014.

\begin{tabular}{cccc}
\hline \multirow{2}{*}{ Hybrid } & & Sowing times & March 03 \\
\cline { 2 - 4 } & February 20 & March 02 & $28.90 \mathrm{bA}$ \\
ADV-123 & $31.30 \mathrm{aA}$ & $30.10 \mathrm{aA}$ & $27.90 \mathrm{bA}$ \\
ADV-114 & $26.10 \mathrm{bA}$ & $28.30 \mathrm{aA}$ & $29.20 \mathrm{bA}$ \\
$1 \mathrm{G} 100$ & $28.50 \mathrm{bA}$ & $29.20 \mathrm{aA}$ & $25.10 \mathrm{cA}$ \\
$1 \mathrm{G} 244$ & $28.10 \mathrm{bA}$ & $26.30 \mathrm{bA}$ & $31.80 \mathrm{aA}$ \\
$1 \mathrm{G} 282$ & $29.60 \mathrm{aA}$ & $26.40 \mathrm{bB}$ & $29.80 \mathrm{bA}$ \\
$50 \mathrm{~A} 10$ & $28.90 \mathrm{bA}$ & $28.40 \mathrm{aA}$ & $33.40 \mathrm{aA}$ \\
$50 \mathrm{~A} 40$ & $27.80 \mathrm{bB}$ & $26.90 \mathrm{bB}$ & $26.10 \mathrm{cA}$ \\
$50 \mathrm{~A} 50$ & $28.00 \mathrm{bA}$ & $25.10 \mathrm{bA}$ & \\
\hline
\end{tabular}

CV (\%) 5.84

Means followed by the same lowercase letter in the columns, or uppercase in the rows, are not different from each other by the Scott-Knott test at $10 \%$ probability level.

The results of grain yield showed that all hybrids presented higher means in the first sowing time when compared to the last, in 2014 (Table 5).

The hybrid 1G282 was usually grouped with those that have the best results for the production components evaluated, but had the lowest mean grain yield in the sowing on February 20, March 02, and March 03, presenting 4,643, 4,374, and $1,227 \mathrm{~kg} \mathrm{ha}^{-1}$, respectively. However, the high incidence of diseases in the third sowing time in 2014, despite the preventive management, may have caused it to present lower grain yield than the others in this sowing time.

Grossi et al. (2013) found similar problems, with sorghum hybrids presenting grain yields affected by phytopathological factors. Chimonyo, Modi and Mabhaudhy (2016) conducted a field experiment with sorghum and cowpea crops and reported effects of environmental factors on the experimental data, and in this case, rainfall of hail affected the number of leaves and leaf area index.

The low mean grain yield of the hybrid $1 G 282$ in the sowing on March 12, 2014 may have affected the grouping of means of the Scott-Knott test and, thus, the hybrid 1G244 was not grouped with other hybrids that presented high means.

The difference between hybrids of different maturation groups is more evident as the sowing time is delayed, with few or no variation in the means between them in the two first sowing times in 
2014; the super early-maturation hybrids had, on average, $14 \%$ higher grain yield than the others, even excluding the data of the hybrid 1G282. Whereas in 2015 , the means of super early-maturation hybrids were $5 \%, 10 \%$, and $20 \%$ higher in the sowing on February 09, February 19, and March 01, respectively.

Table 5. Mean grain yield $\left(\mathrm{kg} \mathrm{ha}^{-1}\right)$ of sorghum crops grown in three sowing times in 2014 and 2015.

\begin{tabular}{|c|c|c|c|c|c|c|}
\hline \multirow{2}{*}{ Hybrid } & \multicolumn{3}{|c|}{2014} & \multicolumn{3}{|c|}{2015} \\
\hline & February 20 & March 02 & March 03 & February 09 & February 19 & March 01 \\
\hline ADV-123 & $6.170 \mathrm{aA}$ & $5.430 \mathrm{aA}$ & $2.840 \mathrm{aB}$ & $7.299 \mathrm{aA}$ & $6.701 \mathrm{bA}$ & $5.470 \mathrm{aB}$ \\
\hline ADV-114 & $6.287 \mathrm{aA}$ & $5.033 \mathrm{aB}$ & $4.298 \mathrm{aB}$ & $7.298 \mathrm{aA}$ & $8.252 \mathrm{aA}$ & $7.060 \mathrm{aA}$ \\
\hline $1 \mathrm{G} 100$ & $5.553 \mathrm{bA}$ & $4.901 \mathrm{aA}$ & $2.955 \mathrm{aB}$ & $5.733 \mathrm{bA}$ & $6.123 \mathrm{bA}$ & $5.517 \mathrm{aA}$ \\
\hline $1 \mathrm{G} 244$ & $6.255 \mathrm{aA}$ & $5.988 \mathrm{aA}$ & $2.297 \mathrm{bB}$ & $7.354 \mathrm{aA}$ & $6.045 \mathrm{bB}$ & $5.705 \mathrm{aB}$ \\
\hline $1 \mathrm{G} 282$ & $4.643 \mathrm{bA}$ & $4.374 \mathrm{aA}$ & $1.227 \mathrm{bB}$ & $6.405 \mathrm{bA}$ & $6.744 \mathrm{bA}$ & $4.464 \mathrm{bB}$ \\
\hline $50 \mathrm{~A} 10$ & $4.921 \mathrm{bA}$ & $5.107 \mathrm{aA}$ & $3.563 \mathrm{aB}$ & $7.314 \mathrm{aA}$ & $7.286 \mathrm{aA}$ & $6.091 \mathrm{aA}$ \\
\hline $50 \mathrm{~A} 40$ & $5.595 \mathrm{bA}$ & $4.638 \mathrm{aA}$ & $2.815 \mathrm{aB}$ & $6.314 \mathrm{bA}$ & $5.833 \mathrm{bA}$ & $3.095 \mathrm{cB}$ \\
\hline $50 \mathrm{~A} 50$ & $7.058 \mathrm{aA}$ & $4.874 \mathrm{aB}$ & $3.675 \mathrm{aC}$ & $6.091 \mathrm{bA}$ & $6.706 \mathrm{bA}$ & $5.906 \mathrm{aA}$ \\
\hline CV (\%) & \multicolumn{3}{|c|}{17.27} & \multicolumn{3}{|c|}{14.39} \\
\hline
\end{tabular}

Means followed by the same lowercase letter in the columns, or uppercase in the rows, are not different from each other by the Scott-Knott test at 10\% probability level.

The comparison between hybrids showed that the hybrids ADV-114 and 50A10 stood out in 2015 as the most productive in all sowing times. The less productive hybrids, regardless of the sowing time, was the $1 \mathrm{G} 282$, with $6,405,6,744,4,464 \mathrm{~kg} \mathrm{ha}^{-1}$, and 50A40, with 6,314, 5,833, 3,095, in February 09, February 19, and March 01, respectively, with the lowest results coinciding with the later sowing times.

Considering the all hybrids within the sowing times, 2014 presented more pronounced decrease in grain yield, with means of $5,810 \mathrm{~kg} \mathrm{ha}^{-1}$ (February 20), 5,043 kg ha-1 (March 02), and 3,206 kg ha-1 (March 12), disregarding the data (March 12) of the hybrid 1G282. In 2015, a less pronounced decrease was found for all the hybrids, probably because the first sowing time was 11 days earlier than that in 2014 , with a mean grain yield of $6,700 \mathrm{~kg} \mathrm{ha}^{-1}$ for the sowing on February 09 and 19, and a decrease to $5,413 \mathrm{~kg} \mathrm{ha}^{-1}$ for the sowing on March 01, although numerically higher than the mean found for the sowing on March 02, 2014 (Table 5).

Considering all data of the sorghum crop, the hybrid ADV-114 was always grouped with the more productive hybrids, regardless of the year and sowing time. This hybrid has a very-early maturation cycle that enables its production in different sowing times, with less time in the field, thus, the plants are less exposed to biotic and abiotic stresses and are faster harvested, which enables a better planning by the farmer. In general, all very-early maturation hybrids present these qualities.
Among the other hybrids, 1G282 stood out negatively, with lower production in all treatments and higher susceptible to diseases than the others. These results contrast with those found by Almeida Filho et al. (2014), who evaluated 25 simple sorghum hybrids and found that the hybrid $1 \mathrm{G} 282$ had higher grain yield in all environments. However, these tests were conducted in regions where the mean temperatures during the second crop season are higher than those of the site of the present experiment, which may explain these different results. Thus, the use of cultivars adapted to the production systems and environmental conditions of the region and an adequate crop management are important factors to maximize grain yield (ARAUJO et al., 2014).

The direct or indirect correlation between grain yield and the production components evaluated (NSPP, LAI, and 1000GW) was not confirmed for none of the two study years. Other production components may have affected the grain yield; for example, Tolk, Howell and Miller (2013) found that the number of grains per panicle affected the grain yield of the sorghum hybrids, despite they had equal 1,000-grain weights.

\section{Maize crop}

The results of DSF of the maize crop in 2014 showed no significant $(p<0.10)$ difference between the hybrids tested, probably because all of them 
belong to the same maturation group (Table 6). However, the results found for the maize were similar to those of the sorghum hybrids of earlier maturation in the same sowing time (Table 1). In 2015 , the DSF was different between hybrids in the first sowing time; the hybrids DKB-290-Pro and DKB-330-Pro had higher DSF, however, the first has an earlier maturation cycle and the second has a very -early maturation cycle.

Table 6. Mean number of days from sowing to flowering of maize plants grown as a second crop in 2014 and 2015.

\begin{tabular}{cccc}
\hline \multirow{2}{*}{ Hybrid } & 2014 & \multicolumn{3}{c}{2015} & February 19 \\
\cline { 2 - 4 } & February 20 & $65 \mathrm{aA}$. & $60 \mathrm{aB}$ \\
DKB-330-Pro & $59 \mathrm{a}$ & $61 \mathrm{bA}$. & $58 \mathrm{aA}$ \\
P-3431-HX & $57 \mathrm{a}$ & $58 \mathrm{bA}$ & $61 \mathrm{aA}$ \\
Formula-TL & $60 \mathrm{a}$ & - & - \\
AG-9010-PRO & $55 \mathrm{a}$ & $67 \mathrm{aA}$ & $60 \mathrm{aB}$ \\
DKB-290-PRO & - & $57 \mathrm{bA}$ & $60 \mathrm{aA}$ \\
DKB-275-PRO & - & \multicolumn{2}{c}{5.28} \\
\hline CV (\%)
\end{tabular}

Means followed by the same lowercase letter in the columns, or uppercase in the rows, are not different from each other by the Scott-Knott test at $10 \%$ probability level.

Comparing the DSF of sorghum and maize crops in 2014, the four maize hybrids evaluated took, in general, 58 days to reach $50 \%$ flowering, whereas the eight sorghum hybrids needed 63 days (Table 6). However, the analysis of the four super early maturation hybrids of same cycle of maize hybrids showed a mean of 59.1 days (Table 1).

In 2015, the mean DSF of very-early maturation maize hybrids were 60 and 59.7 for the first and second sowing times, respectively (Table $6)$. The very-early maturation sorghum hybrids needed 60 and 63 DSF for flowering in the sowing times February 09 and 19, respectively (Table 1). The visual comparison of the different crops showed that the difference between them is very small; thus, real differences between the total cycle of maize and sorghum crops probably does not exist among hybrids of the same maturation group.

In 2014, the number of rows per ear (NRE) did not meet the basic assumptions for the analysis of variance and Scott-Knott grouping test even after the transformation of the data, and the number of grains per row (NGF) and leaf area index (LAI) presented no significant differences between treatments at $10 \%$ probability level by the ScottKnott test. The results found in 2015 are shown in Table 7.

Table 7. Mean of number of rows per ear (NRE), number of grains per row (NGF), and leaf area index (LAI) of maize crops grown with two sowing times in 2015 .

\begin{tabular}{|c|c|c|c|c|c|c|}
\hline \multirow[b]{2}{*}{ Hybrid } & \multicolumn{2}{|c|}{ NRE } & \multicolumn{2}{|c|}{ NGF } & \multicolumn{2}{|c|}{ LAI } \\
\hline & $\begin{array}{c}\text { February } \\
09 \\
\end{array}$ & $\begin{array}{c}\text { February } \\
19 \\
\end{array}$ & $\begin{array}{c}\text { February } \\
09 \\
\end{array}$ & $\begin{array}{c}\text { February } \\
19 \\
\end{array}$ & $\begin{array}{c}\text { February } \\
09 \\
\end{array}$ & $\begin{array}{c}\text { February } \\
19 \\
\end{array}$ \\
\hline DKB-330-Pro & $17.58 \mathrm{bA}$ & $15.67 \mathrm{bB}$ & $34.00 \mathrm{aA}$ & $32.92 \mathrm{cA}$ & $3.16 \mathrm{bA}$ & $3.79 \mathrm{aA}$ \\
\hline P-3431-HX & $19.00 \mathrm{aA}$ & $18.00 \mathrm{aA}$ & $34.75 \mathrm{aB}$ & $37.58 \mathrm{bA}$ & $2.76 \mathrm{bA}$ & $3.15 \mathrm{aA}$ \\
\hline Formula-TL & $13.50 \mathrm{dA}$ & $14.33 \mathrm{cA}$ & $35.59 \mathrm{aB}$ & $39.92 \mathrm{aA}$ & $3.76 \mathrm{aA}$ & $2.99 \mathrm{aB}$ \\
\hline DKB-290-Pro & $17.67 \mathrm{bA}$ & $17.50 \mathrm{aA}$ & $30.33 \mathrm{cB}$ & $33.92 \mathrm{cA}$ & $3.03 \mathrm{bA}$ & $3.63 \mathrm{aA}$ \\
\hline DKB-275-Pro & $15.00 \mathrm{cA}$ & $14.50 \mathrm{cA}$ & $32.50 \mathrm{bA}$ & $32.59 \mathrm{cA}$ & $2.06 \mathrm{bA}$ & $3.24 \mathrm{aA}$ \\
\hline $\mathrm{CV}(\%)$ & & 5.53 & & 3.83 & & 16.59 \\
\hline
\end{tabular}

Means followed by the same lowercase letter in the columns, or uppercase in the rows, are not different from each other by the Scott-Knott test at $10 \%$ probability level. 
The number of rows per ear (NRE) of the cultivar P-3431-HX was higher than that of the other hybrids in the two sowing times in 2015 (Table 7). The hybrid Formula-TL stood out negatively, with the lowest performance regarding NRE. The only hybrid whose NRE varied according to the sowing time was the DKB-330-Pro, which presented the lowest result in the second sowing time.

Despite the hybrid Formula-TL showed the lowest NRE, it presented a high number of grains per row. The inverse occurred for the cultivar DKB-290Pro, which had good results of NRE, but lower result of NGF than the other treatments (Table 7). The cultivar P-3431-HX stood out with higher results for NRE and NGF in the two sowing times in 2014.

The hybrid Formula-TL stood out with a LAI of 3.76 in the first sowing time (Table 7), which was different within the other hybrids and between the sowing times February 09 and February 19. The other hybrids presented no difference from each other nor between sowing times.

The hybrid P-3431-HX had the best results of NGF and NRE (Table 7), but not good performance regarding $1000 \mathrm{GW}$, which was lower than that of the other hybrids in 2014. Similar results were found in 2015 (Table 8).

Table 8. Mean 1,000-grain weight (g) of maize plants grown as a second crop in 2014 and 2015.

\begin{tabular}{cccc}
\hline Hybrid & 2014 & February 09 & February 19 \\
\cline { 2 - 4 } & February 20 & $285.2 \mathrm{bA}$ & $256.1 \mathrm{bA}$ \\
DKB-330-Pro & $405.6 \mathrm{a}$ & $255.5 \mathrm{bA}$ & $236.2 \mathrm{bA}$ \\
P-3431-HX & $354.1 \mathrm{~b}$ & $294.0 \mathrm{bA}$ & $302.4 \mathrm{aA}$ \\
Formula-TL & $398.8 \mathrm{a}$ & - & - \\
AG-9010-PRO & $433.9 \mathrm{a}$ & $318.6 \mathrm{aA}$ & $317.8 \mathrm{aA}$ \\
DKB-290-PRO & - & $358.4 \mathrm{aA}$ & $319.0 \mathrm{aB}$ \\
DKB-275-PRO & - & & 10.32 \\
\hline CV (\%) & 7.17 &
\end{tabular}

Means followed by the same lowercase letter in the columns, or uppercase in the rows, are not different from each other by the Scott-Knott test at $10 \%$ probability level.

The hybrids DKB-290-Pro and DKB-275-Pro stand out with higher mean $1000 \mathrm{GW}$ in 2015 in the two sowing times; but the analysis of other variables, such as NGF, showed not similar positive results. DKB 275 was the only hybrid that presented different $1000 \mathrm{GW}$ between sowing times, with higher result found in the first sowing time.

Only one sowing time was possible to evaluate in 2014, which showed no difference in grain yield between hybrids, with an overall mean of $6.883 \mathrm{~kg} \mathrm{ha}^{-1}$. The individual means are shown in Table 9.

Table 9. Mean grain yield $\left(\mathrm{kg} \mathrm{ha}^{-1}\right)$ of maize plants grown as a second crop in 2014 and 2015.

\begin{tabular}{cccc}
\hline Hybrid & 2014 & February 09 & 2015 \\
\cline { 2 - 4 } & February 20 & $9.100 \mathrm{aA}$ & February 19 \\
\hline DKB-330-Pro & $7.334 \mathrm{a}$ & $9.321 \mathrm{aA} \mathrm{bA}$ \\
P-3431-HX & $6.609 \mathrm{a}$ & $9.871 \mathrm{aA}$ & $6.758 \mathrm{bB}$ \\
Formula-TL & $6.806 \mathrm{a}$ & - & $7.044 \mathrm{bB}$ \\
AG-9010-Pro & $6.783 \mathrm{a}$ & $8.125 \mathrm{aA}$ & - \\
DKB-290-PRO & - & $9.141 \mathrm{aA}$ & $8.259 \mathrm{aA}$ \\
DKB-275-PRO & - & & $8.886 \mathrm{aA}$ \\
\hline CV (\%) & 8.19 & & 13.88 \\
\hline
\end{tabular}

Means followed by the same lowercase letter in the columns, or uppercase in the rows, are not different from each other by the Scott-Knott test at $10 \%$ probability level.

The hybrids presented no differences in grain yield in the sowing on February 09, 2015, and DKB290-Pro and DKB-275-Pro, as well as for the 1,000- grain weight (Table 8), were the only hybrids whose performance was not affected by the different sowing times. 
Considering the hybrid DKB-275-Pro individually, the $1000 \mathrm{GW}$ (Table 8 ) of this hybrid was higher enough to compensate its lower number of grains and provide a high grain yield, higher than those of the other treatments in the second sowing time (Table 9), despite the low number of rows per ear and number of grains per row, components responsible for total quantity of grains per ear. The hybrid DKB-290-Pro showed similar results, and the best results of NRE.

Several studies have shown the direct effect of production components on maize grain yield (FERREIRA et al., 2010; ZUCARELI et al., 2013; ENTRINGER et al., 2014; LU; XUE; GUO, 2017). However, the analyses of the results found in the present study showed a certain compensation between production components, i.e., a hybrid that present low NGF and NRE may present high $1000 \mathrm{GW}$, as in the case of DKB-275-Pro. Moreover, a cultivar that present high NFG and NRE may present a low mean $1000 \mathrm{GW}$, as in the case of the hybrid P-3431-HX.

The hybrid P-3431-HX presented the lowest $1000 \mathrm{GW}$ in 2014 and 2015 (Table 8), but its grain yield was only statistically lower than those of the other hybrids in the sowing in 2015.

A factor that should be considered is that the technical recommendation of this material by seed companies describes the use of a higher population than that for the other commercial hybrids. Population is also an important production component for composition of the production capacity of crops; however, all treatments were sown with homogeneous distribution, as described in the Material and Methods section, due to the complexity of evaluating different populations.

The maize grain yield (Table 9 ) was $16 \%$ and $13 \%$ higher than those of the sorghum grain yield (Table 5) in the sowing on February 20, 2014 and February 19, 2015, and was well higher $(26.2 \%)$ in the sowing on February 09, 2015.

The mean decreases in maize production from the first to the second sowing time was approximately $15 \%$, whereas this decrease in the sorghum crop was near zero, showing a possible higher production stability for sorghum crops in different sowing times.

\section{CONCLUSIONS}

The agronomic characteristics of the hybrids of both crops tested were affected by the sowing time, which was a determinant factor for grain yield. The best sowing times were the earliest used in each year, in this case, February 20, 2014 and February 09,2015 . The sorghum hybrid that presented the best results was ADV-114, which showed high production potential and stability in different sowing times.

\section{REFERENCES}

ALBUQUERQUE, C. J. B. et al. Espaçamento e densidade de semeadura para cultivares de sorgo granífero no semiárido. Bragantia, 70: 278-285, 2011.

ALMEIDA FILHO, J. E. et al. Avaliação agronômica de híbridos de sorgo granífero em diferentes regiões produtoras do Brasil. Revista Brasileira de Milho e Sorgo, 13: 82-95, 2014.

AMADUCCI, S. et al. A. Effect of irrigation and nitrogen fertilization on the production of biogas from maize and sorghum in a water limited environment. European Journal of Agronomy, 76: 54-65, 2016.

ARAUJO, B. L. et al. Parâmetros genéticos em cultivares de sorgo granífero avaliados em safrinha. Revista Trópica CiênciasAgrárias e Biológicas, 9: 51-59, 2014.

BONELLI, L. E. et al. Maize grain yield components and source-sink relationship as affected by the delay in sowing date. Field Crops Research, 198: 215-225, 2016.

CHIMONYO, V. G. P.; MODI, A. T.; MABHAUDHI, T. Simulating yield and water use of a sorghum-cowpea intercrop using APSIM. Agricultural Water Management,177: 317-328, 2016.

EMBRAPA - Empresa Brasileira de Pesquisa Agropecuária. Sistema brasileiro de classificação de solos. 3 ed. Brasília, DF: Embrapa Solos, 2013, $353 p$.

ENTRINGER, G. C. et al. Correlação e análise de trilha para componentes de produção de milho superdoce. Revista Ceres, 61: 356-361, 2014.

FERREIRA, H. A. et al. Componentes de produção e produtividade do milho submetido a doses de nitrogênio no semiárido paraibano. Revista Verde de Agroecologia e Desenvolvimento Sustentável, 5: 90-96, 2010.

FRANCIS, C. A.; RUTGER, J. N.; PALMER, A. F. E. A rapid method for plant leaf area estimation of maize (Zea mays L.). Crop Science, 9: 537-539, 1969.

GOES, R. J. et al. Fontes e doses de nitrogênio em cobertura, no sorgo granífero na safrinha. Revista Brasileira de Milho e Sorgo, 10:121-129, 2011.

GROSSI, M. C. et al. Modeling the impact of global warming on the sorghum sowing window in distinct 
climates in Brazil. European Journal of Agronomy, 51: 53-64, 2013.

LANDAU, E. C.; SANS, L. M. A.; SANTANA, D. P. Clima e solo. In: CRUZ, J. C. Cultivo do milho. 6 ed. Sete Lagoas: Embrapa Milho e Sorgo, 2010, 2 p.

LU, H.; XUE, J.; GUO, D. Efficacy of planting date adjustment as a cultivation strategy to cope with drought stress and increase rainfed maize yield and water-use efficiency. Agricultural Water Management,179: 227-235, 2017.

SHIOGA P. S.; GERAGE, A. C. Influência da época de plantio no desempenho do milho safrinha no estado do Paraná, Brasil. Revista Brasileira de Milho e Sorgo, 9: 236-253, 2010.

SILVA, K. J. et al. Seleção de híbridos de sorgo granífero cultivados no verão em três localidades. Revista Brasileira de Milho e Sorgo, 1: 44-53, 2013.

TARDIN, F. D. et al. Avaliação agronômica de híbridos de sorgo granífero cultivados sob irrigação e estresse hídrico. Revista Brasileira de Milho e Sorgo, 12: 102-117, 2013.

TEDESCO, M. J. et al. Manual de adubação e calagem para os estados do Rio Grande do Sul e Santa Catarina. 10. ed. Porto Alegre, RS: SBCS, 2004. 353 p.

TOLK, J. A.; HOWELL, T. A.; MILLER, F. R. Yield componente analysis of grain sorghum grown under water stress. Field Crops Research, 145: 44$51,2013$.

TSIMBA, R. et al. The effect of planting date on maize grain yields and yield components. Field Crops Research, 150: 135-144, 2014.

ZHOU, B. et al. Maize kernel weight responses to sowing date-associated variation in weather conditions. The Crop Journal, 5: 43-51, 2016.

ZUCARELI, C. et al. Desempenho agronômico de genótipos de milho de segunda safra na região Norte do Paraná. Scientia Agrária Paranaensis, 12: 227 $235,2013$. 